\title{
Digging in: German humanitarians in early Queensland
}

\section{Regina Ganter}

r.ganter@griffith.edu.au

The first group of German settlers arrived in Queensland before it existed on any maps. They came not primarily to seek a better future for themselves, but with the express intention of conducting an Aboriginal mission. This group germinated three of the first four mission attempts in Queensland, and their failure left a significant gap in Queensland's mission effort until the 1870s, by which time the frontier wars were practically over.

Aboriginal people came under siege as Queensland increased its white population twenty-fold (from around 23,000 to nearly 500,000) during its forty years as a colony, mostly through targeted migration ( 88 per cent of migrants were government-assisted) with a European participation rate of around 20 per cent. ${ }^{1}$ Germans became the most significant group of non-British settlers, with close to 15,000 residents in $1891 .^{2}$

German-speakers made a disproportionate contribution to Aboriginal mission in Queensland until World War I. They did not share with the English-speaking churches a background of empire, where Enlightenment philosophes sought to align political conquest with scientific principles. Unshackled by the politics of farflung empire, German science took a decidedly different turn, towards the unity of humanity, the centrality of language and the diversity of culture, with the result that it was largely eclipsed from Anglophone science and sometimes ridiculed. ${ }^{3} \mathrm{~A}$ group arriving in 1838 at Zion Hill (now Nundah in Brisbane) became the lone beacon of mission activity in Queensland, long before the 'century of missions' took hold in Australia. One among this group also instigated missions at Bethesda (1866) and Nerang Creek (1869), south of Brisbane.

These early German mission efforts are the subject of this article, and are considered in light of the whole German missionary effort in Australia, which is the subject of my current ARC project, drawing on much untranslated German source material. ${ }^{4}$ In charge of the group was Reverend Schmidt, who was closely aligned with the Moravian churches in Berlin and who had received theological training in Halle. He thus emerged from much the same intellectual milieu as that recently described by Christine Lockwood ${ }^{5}-$ that is, one aimed at the formation of Indigenous churches rather than the erasure of Indigenous culture, where Christianising was not coterminous with civilising. The remainder of the group were Gossner disciples: practical, pietist 'Godly mechanics'. The colonial setting in which they arrived was rapidly transforming from an Indigenous space into a thriving settler society, and their own attitudes were transformed through engagement with the

122 Queensland Review

Volume 21 | Issue 2 | 2014 | pp. 122-141 | (c) The Author(s) 2014 |

doi $10.1017 /$ qre.2014.21 
expectations, limitations and policy directions placed on them. We see them arrive as apostles of Zion and become veterans of white conquest. They were on every level a social experiment.

To briefly complete the overview of German missions in Queensland, in the late 1880s Lutherans from South Australia and Queensland reached out to the northern frontiers with missions near Maryborough (Mari Yamba 1887) and Cooktown (Cape Bedford 1886; Bloomfield River 1887). In the context of a germination of missions and reserves in Queensland from the mid-1880s, German Moravians from Victoria, in association with Presbyterians, commenced missions on Cape York (Mapoon 1891; Weipa 1898; Aurukun 1904). At the turn of the century, Germans conducted 40 per cent of Queensland missions and reserves. Thereafter, as an increasingly interventionist state government favoured secular reserves over denominational missions, the German missions comprised between 25 and 50 per cent. ${ }^{6}$ All of these German missions were posted at the frontiers and came to be viewed as obstacles when competition for land intensified.

The winding down of the German mission at Zion Hill and the collapse of the Passionist mission on Stradbroke Island the following year (1843-46), left a twentyyear lacuna in the mission effort in Queensland (to 1866). Other denominations did not enter the field until 1871, thirty-three years after Zion Hill was abandoned. These new missions responded to acute labour shortages and the disreputable importation of Pacific Island contract workers, commencing in $1863 .^{7}$ They were also better aligned with colonial strategic goals, and were thus able to attract some public subsidies in a climate of opinion that envisaged the impending disappearance of Aboriginal populations.

\section{Sink or swim pietists}

The group of pioneering Protestant missionaries arriving at the Moreton Bay penal colony in 1838 was to establish a mission at the northernmost frontier of New South Wales, the first of an expected string of Christian missions planned in response to widely publicised Indigenous attacks on shipwrecks, such as the Charles Eaton in Torres Strait in 1834 and the Stirling Castle near Fraser Island in 1836. For those who supported the missionaries, they were part of the civilising spearhead that would make it possible for the approaching tide of settlers to go about unmolested by defending warriors in an undeclared war that was only just beginning. However, the missionaries themselves were inspired by seismic ideas of religious revivalism that posited all of humankind in relationship to God.

They arrived as an apostolic twelve (not counting wives and children), ${ }^{8}$ united in a background of protest nurtured by Pietism, that personal relationship with God, which supplies the strength to defy worldly institutions and rules. The twenty adults shipped on the Minerva in 1838 were mostly in their twenties, energetic and optimistic. They came from non-metropolitan backgrounds in Silesia, Pomerania, a Brandenburg farm and a village near Frankfurt, and they had useful trades: stonemason, carpenter, blacksmith, weaver, tailor, shoemaker, butcher, gardener and bookbinder. They were driven by an idea for which they were ready never to return home: to evangelise and to produce a better world for others, not primarily for themselves. ${ }^{9}$ 
This pietist defiance is evident in the biographies of the two priests among them. Reverend Christopher Eipper (aged 22) had recently completed his training in the Basel Mission Society, and like several other Basel candidates (and indeed the two Dresden-trained missionaries who arrived in South Australia at the same time), he refused to take a vow of obedience to a Bishop, a standard requisite for ordination in London. Eipper was hastily prepared for a posting to the Australian colony in June 1837 by ordination by German and French clergy (without the obedience vow) and was married to a daughter of missionaries. Reverend Wilhelm Schmidt was a pastor in the Bethlehem Bohemian church in Berlin. He was the first student with any theological training in the new missionary training institute commenced in Berlin in 1836 by Johannes Evangelista Gossner (a former Catholic who was also connected to the Bohemian church). The Gossner Mission itself was a protest against the dogmatic Lutheranism of the two other missionary training colleges in Berlin: the old-Lutheran Jänicke society (since 1800) and the Berliner Missionsgesellschaft, which was affiliated with the Prussian state church (since 1824).

The deeply pietist Gossner, now in his early sixties, sought to circumvent the doctrinal enmities that were corroding Lutheranism. Until the mid-1880s, German Protestant evangelists had to rely on their British and Dutch contacts to place candidates in the colonial world, and Gossner imitated the supra-confessional Basel Mission Society, which used the conduit of Dr C. F. A. Steinkopf in London to arrange placements for young German Lutheran missionaries in the British Empire. The Gossner mission began with six young artisans who had been turned away by these other missionary training institutions. Gossner personally instructed his first apostolic twelve in Bible readings and hymn singing, and their training was completed the following year upon the arrival via London of a request from the Australian immigration activist John Dunmore Lang. The Gossner school was an experiment, and so were its first trainees, most of whom were sent to Queensland in 1838.

In Australia, 'Aboriginal mission' had until now meant opening a school for a few years (Parramatta 1820-28), sending a priest to the frontier (Threlkeld ${ }^{10}$ at Lake Macquarie, 1824-41; Wellington Valley 1832-42) or taking in some supposed orphans (Swan River, 1836, as well as various pastors and well-established families). The greatest effort towards Aborigines had been expended in Tasmania, with the para-military Black Line rounding up Indigenous people to clear the land for the settlers (1830).

It was not a Protestant concept to send out one or two priests supported by a group of sturdy artisans with minimal training and useful skills to germinate a miniature productive economy; this was essentially the monastic model with which the Catholic Church had colonised Europe, and that was imitated by the Unity of Brethren, colloquially called the Moravians. Gossner in Berlin was the first to trial the Moravian model for the Lutherans, possibly inspired by his connection to the Bohemian church. As the 'colonists' could not expect to be funded from home, and nobody was going to underwrite their success, they were in a sink-orswim situation. Since they had their wives and children with them, they usually swam. 'I promise you nothing; you must go in faith,' Gossner told this group. ${ }^{11}$ To immigration promoters and colonial governments, the 'Moravian model' was attractive because it was both Protestant (theologically aligned with the British 
Empire) and 'self-supporting'. The Zion Hill collective had the promise of public subscriptions matched pound for pound by the colonial government, and the rentfree use of some Aboriginal land.

The only one among the group with any medical training fell victim to typhoid before disembarking in Sydney after attending patients on the voyage. His widow married one of the other artisans in the party. This left three bachelors, of whom two were eventually excluded from the mission, 'having been guilty of an offence which could not be overlooked'. ${ }^{12}$ In typical fashion, a blanket of silence extinguishes any further trace of this episode. The contacts with Indigenous people at Zion Hill were generally convivial, and J. D. Lang, publicising the arrival of this party, made sure to specify that most of the group were married, all were pious and all were trained unlike some others who had 'nothing but their mechanical employments to recommend them' (a veiled reference to Tasmania's George Augustus Robinson). ${ }^{13}$ The experiment was a group that was culturally cohesive, economically sustainable and trained in evangelising.

\section{Apostles of Zion Hill}

They named the hill on the reserve set aside 7 miles north of the government station at Eagle Farm 'Zion Hill' - the place from which Christ's light shines forth. The creek that ran through the mission land became Kedron Brook after the watercourse on the eastern boundary of Jerusalem (2 Sam 15:23) that separated wilderness (areas where other deities were worshipped) from civilisation (Jewish monotheism), and that flushed out the debris and filth of the city in its seasonal gush.

There was no shred of doubt that the mission was established on Aboriginal land. The Yaggera and Turrbal, who were neither scarce nor nomadic, had substantial dwellings in densely populated, seasonally occupied settlements connected by wellestablished paths. Within the first few months, about thirty locals settled near the mission, about ten began to attend Sunday service (mostly in German) and four stayed overnight. Eipper and Schmidt had learned Hebrew and English, and many of the Indigenous people of Moreton Bay, having been in contact with the convict settlement and its escapees for nearly fifteen years (since 1824), also spoke English. They began to adopt some of the communards as brothers, and to show them around.

The missionaries' accounts suggest a good deal of mutual curiosity and a willingness among the Indigenous people to accommodate the strangers. In August 1841, Reverend Eipper and Wagner were invited to visit an important initiation ceremony at Deception Bay. Several named men ${ }^{14}$ (one from the Bunya Mountains) and a group of women led the missionaries. The men showed the two Germans where to camp and where to bury provisions for later, and advised them on how much of their food to share at different encounters. Diplomatic talks were held with people from Humpy Bong (Redcliffe), Toorbul (north Brisbane), Bunya and Yarun (Bribie Island) about the possibility of establishing a mission in their respective countries. The day before the ceremony, the party went to Bribie Island for talks, where they sheltered from a strong wind in 'the largest huts we ever have seen, twenty feet in length': 
The natives of Toorbal had all along expressed a desire that we should cultivate ground at their own places of abode, and especially Naimany, the Lord of Yarun, wished us to do so in his island, but we found the soil very sandy, so that we could [not] think of acceding to his wishes ... When the Toorbal and Bonyer natives heard that we had not found the soil of Yarun eligible for cultivation, they seemed to rejoice in it, and invited us to inspect their own ground tomorrow. ${ }^{15}$

Apart from the serious business of inducing the newcomers into proper behaviour and holding diplomatic talks, a good deal of mutual teasing also occurred. While crossing back to the mainland from Bribie Island the next morning, the missionaries mocked the young men who were decorated for the ceremony. Why did they go to all that trouble? The young men retorted with perhaps the only argument that the youthful Germans would have understood: 'Well, the ladies will see us.'

After the ceremony, Wagner went with his 'brother Anbaybury' to his home territory of the Bunya Mountains, while Eipper, suffering from sore feet, preferred to go straight home. Not being accompanied by women to pound bungwall for them, Eipper's party ran out of food and, sitting around the campfire with empty bellies and low spirits, Wunkermany and Jemmy Millboang challenged Reverend Eipper to check in his clever book whether Wagner's party was faring any better. Eipper denied that he had any such book with him, so one of them untied Eipper's bundle, took out the Bible, opened it randomly and read out: 'Mr Wagner, large kangaroo!'

This joke had emerged from an earlier incident at the mission, when an axe had gone missing. While a group was discussing the missing axe, one of the brethren, who was immersed in a book, stated the name of the thief without looking up. It looked as if he were reading the answer from the book. In response, Wunkermany declared that his pipe was also missing - why did the brethren not also check their book about who took that? Perhaps this campfire joke was directed at both Reverend Eipper, with his clever book, and Wunkermany who, after all, gave the missionaries the benefit of the doubt and knelt down with them during prayers.

Meanwhile, Wagner was engaging in further diplomatic negotiations after the ceremony. Having proclaimed to Anbaybury's people that the soil in the Bunyas was good enough for mission gardens, the locals declined to take him any further inland. The men promised that if the missionaries would only come with hoes and axes, their women would willingly work in the gardens, and while the crops were ripening, they would personally watch them day and night without sleep. 'But it was necessary to have fire arms, lest strange natives should rob them.'

The missionaries understood the diplomatic implications of these negotiations quite well. The purpose of taking the strangers around was clearly to introduce them and to negotiate about sites for further missions and their attendant supplies.

\section{House of hunger}

Although the Zion Hill group was loaded with implements and material possessions (compared with an Aboriginal camp), their supplies were not endless, and sometimes the German utopians had to beg or borrow food at the convict settlement. This made them less interesting to the Jagara (or Yaggera, or Turrbal/Turubul) and Quandamooka, who only visited when it suited them. 
The call for prayer at the mission, a tin drum as ersatz church bell, broadcast far and wide when the colonists were not out guarding their crops. When the Germans resorted to firing guns to scare off marauders in 1840, the Moreton Bay commandant demanded an explanation. ${ }^{16}$ The balance of power had not yet tipped against Indigenous people, and it was still possible to play one set of strangers off against another. By 1843, when Sydney Bishop Polding came to establish the first ever Catholic mission in Australia, he observed, not without satisfaction, that at Zion Hill:

The blacks have taken a prejudice against them. They call their house a house of hunger, because they get nothing ... They complain bitterly that the Germans invited them to work and then kept the crops for their own families. ${ }^{17}$

Having learned just this lesson, the young Quandamooka men agreed to work the gardens for the four Passionist missionaries trying to establish themselves at Stradbroke Island, but only on the condition that they would be entitled to the harvest. ${ }^{18}$ That settled the matter: the Italian and Swiss priests at Stradbroke Island never attempted any agriculture. They too often went hungry. Unlike the Zion Hill priests, they did not learn the local language, did not attempt to conduct a school and spoke even less English than the Zion Hill Germans. Despite a massive comet in 1843 having guided these wise men to the 'precise place' of their future mission on Stradbroke, three of the four missionaries left in $1846 .{ }^{19}$

By this time, Zion Hill had been shaped into neatly arranged houses, fringed by orchards and surrounded by well-ploughed fields carrying straight lines of crops like corn, sweet potato and other European plants, worked with European tools and introduced cattle. It looked like a perfect cultural transplant.

At the same time, the immigrants Anglicised their names and were learning English, struggling to acculturate. Gottfried Hausmann became Godfrey Haussman, Nique became Niquet and Rodé became Rode. This is how the streets and places that were named after them are now spelled. Zillmann's name is enshrined in the suburb of Zillmere. Tom Petrie, who grew up on his father's Pine River property and spoke the local dialect, maintained that the Aborigines 'poked fun' at the missionaries for their poor English. Twenty years later, giving evidence to a public inquiry, Petrie upheld that, for any future mission to be successful, 'the missionaries would have to be a little different from the last' because those at Zion Hill 'were unable to speak English':

\section{Q. 33: They can speak English now?}

Tom Petrie: Yes, I believe they can. ${ }^{20}$

Such migrant disadvantages are not easily forgotten. The Zion Hill group tried to engage with Aboriginal people, showing them how to work the introduced tools to produce the exotic crops. They paid for work and only engaged Aboriginal workers if they could afford it. While the parents were working, Reverend Schmidt conducted a school for the German and Aboriginal children using as much English as he could manage. According to Bishop Polding, 'The children are taught in English; and it was lamentably ludicrous to see so much good pains, as $\mathrm{Mr}$ Smith evinced, to make these little creatures answer precisely as parrots might. ${ }^{21}$ 
Government officials failed to see the wisdom of schooling Aboriginal and German children together, but the Zion Hill group drew from this experiment the unshakeable conclusion that Aboriginal children were exactly as adept at learning as their own, and they never wavered from that position. ${ }^{22}$ In 1842 , the convict David Bracefield returned to Moreton Bay after living several years with Aboriginal people in Wide Bay, and Reverend Schmidt recruited his help to translate the scriptures into a local language. ${ }^{23}$

Public interest waned quickly and subscriptions dropped from $£ 310$ in 1838 to $£ 93$ in 1841. In that year, Mr Steel's Infant Training School in Sydney's Pitt Street managed to collect $£ 1.10$ for the Moreton Bay mission. Five years into the experiment, with the shadow of termination already hanging over the mission, fellow German Ludwig Leichhardt visited in 1843 with Charles Archer from Durundur Station (Woodford):

The missionaries have converted no black-fellows to Christianity; but they have commenced a friendly intercourse with these savage children of the bush, and they have shewn to them the white fellow in his best colour. They did not take their wives; they did not take bloody revenge when the black fellow came to rob their garden. They were always kind, perhaps too kind. ${ }^{24}$

However, the measure of kindness and conversion was not the real issue. Governor Gipps had visited in 1842. He was planning to open Moreton Bay to free settlement, and advised the missionaries to move 'further afield'. The thriving Zion Hill gardens and orchards proved that the mission was on fertile land, and it would thus be in the way of settlement. The missionaries explored alternative sites again, and in the process were attacked at Burpengary in Deception Bay, where Godfrey Haussman sustained a severe leg injury that was to trouble him for the rest of his life. Reverend Schmidt accompanied nine Aborigines to the Bunya Mountains and Wide Bay area, and heard that squatters were poisoning Aborigines. ${ }^{25}$ The contact zone was fast becoming more violent.

The apostles at Zion Hill had been busy eking out an existence and had left all public relations to their sponsor, J. D. Lang, who for his part was more interested in populating the new colonies with Presbyterians and separating 'Cooksland' from New South Wales. ${ }^{26}$ Lang did not actually see Zion Hill until November 1845, some years after the mission committee resolved in 1843 to abandon the mission instead of moving it 'further afield'.

\section{We are staying}

The Zion Hill communards had ploughed all their efforts into the mission's land for five years to make it productive. Their last subsidy had been $£ 186$ for their group of twenty adults and more than a dozen children. They were now resolved to dig in their heels. They could survive without public money, and there was certainly no returning. Lang had found it difficult enough to raise their passage money to the colony; nobody was going to pay their fare home. Until the formation of plans to open the land for free settlement, there had been almost no interest in the mission's progress. Now, Zion Hill was roundly pronounced a failure. Bishop Polding (somewhat ill-informed) reported that 'a native settlement had been undertaken by 
German Lutherans, and had completely failed, all the ministers connected with it being farmers'. ${ }^{27}$

The government opened Moreton Bay to free settlement in 1842 and withdrew its funding in 1843. Reverend Eipper left for New South Wales in 1844, while Reverend Schmidt stayed on until 1845 before becoming a missionary in Samoa. In 1848 , the Zion Hill pragmatists officially abandoned trying to convert the Indigenous inhabitants. The government had subdivided the land of the mission, and six of the group bid at auction to buy some of it back, in parcels as small as 5 acres. ${ }^{28}$ The place became known as German Station.

Zillmann, a former Prussian blacksmith, became one of the respected residents, supporting J. D. Lang to become the representative for the Stanley District in 1854. ${ }^{29}$ Johann Gottfried Wagner, a former Silesian shoemaker, became the first commercial pineapple grower in Queensland. He obtained his pineapple plants from Reverend Johann Handt, who had introduced the fruit from India and propagated them in a garden near the later Treasury buildings in Brisbane in around 1838, replicating earlier acclimatisation experiments in Sydney. The plants were subsequently distributed among neighbouring settlers and became a major agricultural activity in Queensland. J. W. Gericke, a viticulturist, introduced another important industry for southern Queensland. ${ }^{30}$ The Zion Hill partisans became acknowledged as the first free settlers in Queensland, having produced its first freeborn babies. They helped to transform the cultural and environmental landscape of the colony.

Within a short time, a new task offered itself. A failed revolution in 1848 tipped off an avalanche of emigration from Germany and added to the land-rush into northern New South Wales. In January 1849, the Fortitude, Chaseley and Lima landed 550 more 'pious Protestant dissenters' at Moreton Bay, also recruited through J. D. Lang. In 1855, 1,000 Prussian labourers arrived under three-year contracts for farm work, mostly in Toowoomba. The competition for waterfront real estate was keen, rents were rising and the new settlement prospered under the sheer thrust of new arrivals. ${ }^{31}$

The new settlers were preoccupied with carving out their own futures, and little thought was given to assisting the Aboriginal people they were displacing. The Zion Hill group kept the idea of mission work afloat. Zion Hill veteran Haussman reported from Brisbane town in 1855 that he was working among the 'savages who have built a little Chaple for me'. ${ }^{32}$ A meeting in 1855 to recommence a mission brought together the German Station men, ${ }^{33}$ eight other locals (including Andrew Petrie) and Reverend William Ridley, also affiliated with Lang; however, nothing came of it. ${ }^{34}$

Population growth was expedited once Queensland received its own legislature in 1859, and appointed agents to recruit new immigrants. Pressure on land and Indigenous food resources increased. Queensland did not have an Aboriginal Protection Board, and there was no targeted protection legislation until 1897. The only legal mechanism that the new colony inherited from its parent colony for dealing with Aboriginal people was the Native Police, whose job it was to protect settlers and 'disperse' Aborigines. ${ }^{35}$ A Native Police camp at Sandgate made several raids in retaliation for cattle killing, and in one instance Aborigines camped near German Station were attacked at night by armed troopers. The Aborigines retaliated by killing a large number of cattle and demonstratively leaving them untouched. A 
few months later, Zillmann and Gericke met some of the culprits at the Pine River who told them clearly that the slaughter had been their revenge. ${ }^{36}$

Atrocities committed by the Native Police led to an 1861 parliamentary select committee to which two Zion Hill troupers, Rodé and Zillmann, gave evidence. Both still thought that their mission could have been successful if only it had not been starved of funding. ${ }^{37}$ Under questioning from the committee, which was bent on demonstrating that missions achieved nothing, August Rodé affirmed: 'I would not have given it up if we had received any support, I would have stuck to it'. John Leopold Zillmann produced evidence from Victoria that it was possible to achieve conversions, where Nathaniel Pepper ${ }^{38}$ had become a cause celebré in mission circles, and cited other instances in which missions had produced black preachers. He spoke strongly against the idea of declaring reserves to which Aboriginals would be removed. He argued that any approach to Indigenous people must be liberal and based on inducements rather than compulsion. Zillman had been harbouring the idea of a 'missionary cotton plantation' along the lines of mission work conducted in the Pacific, and had approached the German migration agents Johann Heussler and Jordan with this idea. ${ }^{39} \mathrm{He}$ wanted another group of Gossner missionaries sent out to begin again. The committee was incredulous:

Q. 44 A company of missionaries? Yes.

Q. 45 Missionary agriculturalists? Yes. I have found the blacks to be much the same as our own race,--some very industrious, and some very lazy, - some very intelligent, and some very dull. ${ }^{40}$

Zillman thought he could do it with $£ 1,000$ per year for five years plus a start-up grant for buildings. Eventually, the committee embraced the idea and particularly recommended it. It became the industrial mission model of the labour-starved 1870s. However, neither the Baptist lay-preacher Zillmann nor Reverend Haussman (who started just such a mission in 1866) became beneficiaries of public funding. Instead, support was directed to a secular enterprise in Mackay.

German migrant communities kept swelling in Queensland, Victoria and South Australia, and five of the Zion Hill men were ordained as their Lutheran, Presbyterian, Baptist or Methodist pastors. ${ }^{41}$ The training and ordination of migrant pastors became a contentious issue. In Germany, an increasing number of missionary training colleges offered alternative pathways for 'native mission' and home mission among German migrants. Most candidates could not afford to enrol at a university, nor would they likely have been accepted. Their ordination as pastors was not uncontroversial, either in Germany or in the colonies. As more of the Zion Hill colonists became ordained, an anonymous critique appeared in the Queensland Daily Guardian in 1864, questioning

what claim the German clergymen in Brisbane really have to that important position ... to enjoy all the emoluments and respects paid to that position, instead of carrying on the handicraft to which they had been trained at home in Germany, for I understand that none of them ... came near a University ... (one of them is a Presbyterian clergyman) who has been nothing more than a cobbler in Germany, and who was sent out with other handicrafts men and two missionaries to teach the blacks his noble craft. ${ }^{42}$ 
The 'cobbler' was a reference to shoemaker Wagner from Zion Hill. More controversially still, Reverend Haussman, after training at Lang's Australian college (established in 1850), himself went on to ordain laymen after a brief period of instruction. ${ }^{43}$

These alternative pathways were driven by the fact that the demand for Lutheran pastors was rapidly outgrowing supply. In 1855 , more than a quarter of new arrivals in Queensland were Germans, and more than a thousand Germans had settled at Ipswich, Boonah, Engelsburg (Kalbar), Rosewood, Lowood, Marburg, Minden, Gatton, Laidley and the Darling Downs, with Toowoomba as its centre. ${ }^{44}$ By 1891, Queensland was home to 23,400 German Lutherans, still concentrated in the south-east corner, with forty German parish schools. ${ }^{45}$ They included draftresisters, political refugees, 49ers from America, economic migrants and religious refugees. Their pastors reproduced the diversity in Germany of old-Lutheran, reformed Lutheran, pietist, confessionalist and supra-confessional orientations, and formed 'a gaggle of synods', often in close competition with and proximity to each other. They disagreed on interpretations of the Augsburg Confession, the role of lay preachers, millenarianism, relations with the Prussian State Church and transubstantiation, but even more seriously, they had personal clashes cloaked in doctrinal disputes. ${ }^{46}$

Zion Hill veteran Godfrey Haussman (1811-1901), formerly Saxon butcher Gottfried Hausmann, was ordained in Sydney as a Presbyterian pastor in 1853 and conducted parish work in German migrant communities in Maryborough, Germantown (Geelong), Brisbane and the Beenleigh area. He was involved in the formation of six Lutheran parishes in south-east Queensland. As pastor of the Nazareth congregation in Brisbane (1862-66), Haussman settled a further wave of German migrants in the Logan River area, where the first land came on the market in October 1863. In January 1864, the Susanne Godeffroy landed 451 Germans, who Haussman invited to camp on his church grounds. He collaborated with Heussler to secure land on the Logan River for a German settlement, and conducted a large group in February 1864 to the site (now Waterford). Eleven families from the rural Uckermark north-east of Berlin became the nucleus of the 'Bethania' congregation (named after the miraculous healing pool in Jerusalem). They were old-Lutherans, fiercely resisting the pressures in Bismarck's Prussia towards church union. Doctrinal correctness had galvanised them into leaving home, and they consequently had no interest in supra-confessional pietism. $^{47}$

Haussman, on the other hand, attended the interdenominational prayer meetings of Wesleyans, Free Methodists, Congregationalists and Presbyterians. His supraconfessional orientation had been shaped by his Gossner training, his association with J. D. Lang and his ordination as a Presbyterian pastor. His faith was pragmatic rather than dogmatic, in stark contrast to many of the German Lutheran migrants who were arriving. His biographer suspects that he was driven out of Germantown in Victoria because of his 'unorthodox' and 'unconfessional' teachings ${ }^{48}$ Haussman continued to try to engage with Aboriginal people, but his unconventional attitudes were to present a lasting obstacle to realising his dreams of Aboriginal mission, as he could not galvanise the necessary support. During the 1860s, Haussman became the only active missionary in Queensland, trying to insert a humanist effort into the rush for land. ${ }^{49}$ 


\section{We begin again where we ceased years ago}

In 1866, three influences converged on fifty-five-year-old Pastor Haussman. First, the Bethesda congregation rejected him as their parish priest for being 'too unconventional'. Second, more Gossner-trained missionaries arrived from Germany ready for ordination, including Haussman's own son, John. ${ }^{50}$ Third, towards Christmas, as around 200 Indigenous people converged on the area (Haussman thought for a corroboree), some of the men made themselves known to Haussman, saying ' $\mathrm{Fa}$ ther, don't you know us?' They had attended school at Zion Hill more than twenty years earlier, and now sported substantial beards. One of them was Kingkame (also referred to as Kingkema or Kingcame). 'Naturally the joy was mutual that we saw one another again. Our station was visited daily. ${ }^{, 51}$

This gave Haussman the impetus to start Bethesda mission on his property in the Albert-Logan River area (1866-81): 'We begin again where we ceased years ago. ${ }^{52} \mathrm{He}$ found the place 'ideal for mission', 'fairly removed from the large centres of population as well as from the degrading hotels' ${ }^{53} \mathrm{He}$ now had young helpers in his son John, ${ }^{54}$ Burghardt as his parish assistant (until 1867) ${ }^{55}$ and Guhr as mission assistant (until 1870). ${ }^{56} \mathrm{~A} 6 \times 12$ metre brick church was ready for Christmas 1867.

The Yugambeh people gathered again in November, and Haussman offered them five shillings a week and rations to come to live on the mission. The expectation was that they would work and pray together. Kingkame brought his family to the daily gathering under a tree for hymns, prayer, reading from the New Testament and subsequent explanation. The Yugambeh encouraged Haussman with questions and promises to reform themselves. ${ }^{57}$ On Sundays, they received clean clothes to attend Haussman's two-hour service held in German; they sat 'quite still and with great devotion' and afterwards praised him: 'Father, you have preached mightily. ${ }^{58}$ The graphic image of Jesus nailed to the cross in a small illustrated booklet aroused particular interest - perhaps it was disconcerting evidence of the practice of human sacrifice among the whites. ${ }^{59}$ At any rate, it is most likely that the Yugambeh had an entirely different perspective of these proceedings from Haussman. ${ }^{60}$

One Aboriginal man called Jack addressed Haussman as 'Papo', ${ }^{61}$ and attended reading and writing instructions from October to December 1867 . When Jack left in January, he took a catechism with him and undertook to teach his people about the Bible, to bring more recruits to the mission. That is the last trace of Jack in Haussman's reports. ${ }^{62}$ Kingkame also expressed the wish to become a Christian in that year. In 1869, a group of Nerang people stayed at the mission for several weeks to clear 10 acres of land ready for planting corn, at $£ 1$ an acre. In 1870, Haussman reported that he had erected huts near his home that were accommodating fifteen persons. His kitchen served as dining room and was used for services. 'Here the natives can see actually what it means to live as a Christian and pray as a Christian'.63

Buoyed by such small successes, Haussman liaised with the Nerang Creek people to establish another mission some 50 kilometres from Bethesda. ${ }^{64}$ Parcels of land were selling rapidly at Nerang Creek, and Haussman acquired 100 acres of river frontage near Gilston (Gold Coast hinterland) in June 1869 and leased another 400 acres in February 1870. The Queensland government temporarily reserved 100 acres for an 'Aboriginal industrial mission' in August $1871.6^{65}$ Haussman saw this as a government not following through on its promises. ${ }^{66} \mathrm{He}$ meant his effort to be neither temporary nor secular. There was little support from the local 
Lutheran fraternity, and the Nerang Creek mission ran into sand. ${ }^{67}$ By February 1878, two mission workers had cleared 8 acres of bush and planted 3 acres with corn and some vegetables, but there was still no ordained missionary and the reports never mentioned any Yugambeh people. In January 1879, the Nerang reserve was cancelled and the land offered for public selection.

Bethesda Mission ran for some fifteen years (1866-81) and was the only mission in Queensland until George Bridgman started a similar initiative in Mackay in 1873-74. Indigenous people attended Bethesda sporadically, although often none came for months and there were no conversions to register. The Queensland government and its 1876-77 inquiry into the condition of Aborigines in Queensland, chaired by Anglican Bishop of Brisbane Matthew Hale (appointed in 1875), completely ignored the mission, and in 1881 Haussman finally gave up. Participating in the emerging small-scale sugar plantation industry of the Albert-Logan area, this sink-or-swim pietist had purchased land on the Logan and Albert rivers and at Nerang in the name of J. G. Haussman \& Son, representing his life savings of $£ 5,000$. His first commercial sugar crop was harvested in 1872 and Haussman took out a mortgage for a $£ 2,000$ crushing machine. However, with all the new German settlers in the area having received the same advice, sugar prices dropped, and three dry years, together with an attack of rust on the crops, compounded Hausman's debts until his home, the church and the crushing machine were repossessed in 1884.

\section{Industrial mission}

George F. Bridgman (also spelled Bridgeman in government reports) formed the Association for the Employment and Protection of Aborigines in Mackay with other sugar-planters and appealed for government assistance in 1874. He sought to demonstrate that local Aboriginal labour was 'as good and reliable as that of any other colored laborers - not excepting South Sea Islanders'. His aim was to employ the adults and school the children on special labour reserves. ${ }^{68}$ For a while, he collaborated with the Catholic Father Pierre Bucas, but he made no claim to evangelising among the adults or to aspire to conversions. A further special inquiry in 1876 vindicated the government subsidy of $£ 600$. This subsidised and primarily secular experiment ran for about seven years (c. 1873-79). ${ }^{69}$

It was clearly the importation of Pacific Islanders from 1863 that revived the idea of 'industrial mission' as a training ground for Aboriginal agricultural labour in the 1870s. Industrial mission reserves were gazetted in 1877 at Mackay, Bribie Island and Durundur (Woodford), where Catholic Father Duncan McNab established himself (1877-1905). McNab tried to gain individual freehold land for Aboriginal people at Logan, Bribie Island and Durundur, but had to settle for 'reserves'. He recommended Tom Petrie as a suitable supervisor to employ Bribie Islanders in timber-getting and a commercial fishery $(1877-8) .{ }^{70}$ That the McIlwraith government (1879-83) cancelled all three reserves ${ }^{71}$ must have confirmed for Haussman and $\mathrm{McNab}$ that temporary reserves were not a secure footing for a sustained effort. However, as in New South Wales, Victoria and Western Australia, the government did not countenance granting freehold to Aboriginal people, and generally made it a condition of subsidy that a mission was not on private land. ${ }^{72}$ 
As the pioneer of 'industrial mission' in Queensland, Haussman had been struggling against public perceptions that he was running a private business with cheap Aboriginal labour. His mission was on private land, and had no mission board to oversee the work until 1869 . There was no support to speak of: donations peaked at $£ 20$ in 1869 before dropping to $£ 3$ per year. Haussman also struggled against the perception that Aboriginal people were a lost cause. A correspondent of the German Lutheran newsletter Australischer Christenbote dismissed Haussman's efforts in August 1877, expressing the widely shared opinion that 'the intellectual capabilities of our natives are so small that it seems nearly impossible to interest them for any higher purpose'. The paper's editor, a Haussman supporter, rebuked this with an editorial reference to the successes of the South Australian Lutherans at Yorke's Peninsula and Cooper's Creek and the Moravians in Victoria. ${ }^{73}$ German Moravians had become active in Victoria and South Australia with missions at Lake Boga (1851), Ebenezer (1859), Ramahyuk (1863) and Lake Kopperamanna (1866). In view of the apathy of government and settlers, Haussman had already appealed for help to the German Moravian headquarters in Herrnhut in 1875, without success. ${ }^{74}$ Bishop Hale's report in 1877 also hoped for Moravian involvement at Nerang Creek or Mackay, but it was to be another ten years before the Moravians started to scout in north Queensland for new missionary ventures, seeding the idea for Bloomfield River in 1885 and setting up Mapoon in 1891.

Haussman withdrew from the business in 1881 and discontinued the mission effort amidst what was later referred to as 'some other scandals which offended many congregation members'. ${ }^{75}$ Others felt that he was 'simply not the administrator to carry out this work', and pointed out that none of his missions resulted in any baptisms. ${ }^{76}$ Haussman felt that 'people can think of me as they like, I know that I stand in God's grace in order to pursue a particular task until my Saviour calls me out of this life'. ${ }^{77}$

Haussman did not feel that his missions had failed so much as the government had failed them. Queensland had possibly the largest Aboriginal population of all the Australian colonies (estimated at 20,000), yet it had the smallest budgetary expenditure on them (except Tasmania, which had a zero budget allocation). Several mission attempts folded within a year, ${ }^{78}$ and so far only three others in Queensland had succeeded for any length of time. ${ }^{79}$

To put some perspective on the failure to achieve baptisms, the Moravians, generally lauded for their successes, took thirty years to produce conversions among the nomadic Greenland Inuit. In Papua New Guinea, the Lutherans under Reverend Johann Flierl took thirteen years for the 'first fruit' of two boys, and seventeen years to baptise any adults. ${ }^{80}$ It was not a realistic expectation for Zion Hill to achieve baptisms in five years. For its part, Bethesda did not have any staff dedicated to achieving conversions. This made it difficult to explore the local language and culture, considered so central in Lutheranism, and there was no funding to attend to the material needs of the Yugambeh.

On Haussman's ninetieth birthday, two months before his death in 1901, a public celebration was held, with a money collection amounting to more than $£ 100$. Congratulatory messages came from German congregations in Victoria and Queensland and from Sir Samuel Griffith. The German Kaiser even awarded him a Red Eagle Medal, whatever the old rebel might have thought of that. He was 
now one of the oldest Germans in Queensland and their oldest preacher. ${ }^{81}$ They allowed him to forget his failings - he had done his best.

\section{Conclusion}

The Zion Hill experiment had a subtle but far-reaching influence on humanitarian approaches to Aborigines in Queensland. Witnessing the development from a convict settlement to a separate colony and then to the federation of a nation, Haussman tried to keep alive the idea of ministering to Indigenous people through the changing dynamics of race relations. In the process, he was involved in pioneering two different mission models. The first of these was the 'Moravian model' of a Christian village of artisanal colonists led by one or two pastors. Once this model had outlived its frontier function, the government withdrew its support for the Zion Hill experiment, which - like the Hermannsburg Lutheran mission to South Africa in the $1850 \mathrm{~s}$ - disintegrated into individual farms. ${ }^{82}$ Zillmann, also from Zion Hill, tabled the second model: a form of non-secular industrial mission, which Haussman implemented in 1866 at Bethesda. Bethesda provided opportunities to 'work and pray' according to the seasonal calendar of the Yugambeh and the daily rhythm of a farm. Later secular private missions tended to garner praise and subsidies, whereas Haussman's efforts in the 1860s were largely ignored. Perhaps Haussman preached too mightily.

The dogmatic differences between Lutherans prevented them from galvanising into a cohesive force in Queensland, as in South Australia and Victoria. Moreover, their training colleges in Germany had no agreed position on how to approach the conversion of Indigenous people. Lockwood observes that the Dresden-trained missionaries who came to South Australia at the same time as the Zion Hill group arrived in Queensland ultimately aimed to form Indigenous churches. ${ }^{83}$ Language acquisition and interacting in the vernacular were considered essential, while transforming the local culture was not part of the missionaries' agenda: they did not resist polygamy and did not insist on the wearing of clothes. These missionaries were not engaged in the 'civilising' project, with their strategic alignment with government consequently collapsing. ${ }^{84}$ As a Gossner disciple, Haussman felt he had a role to play in looking after the worldly requirements of Aboriginal people, and did not find access to their language important. He understood himself as a 'godly mechanic' sent out to spread the gospel without financial backing and without cumbersome theological direction. After all, 'Father Gossner himself did not work under any Mission Society'. ${ }^{85}$ Nolan argues that Gossner evangelism required that converts too were instilled with the capacity and responsibility for economic activity: Christian modelling, devotional Bible study and paid labour were part and parcel of the conversion. However, like the Dresden-trained pastors in South Australia, Haussman found it difficult to forge links with the Lutheran migrant community who held fast to dogmatic differences and offered only lukewarm support for missionary work.

While the residential missions commencing in the north from the 1880s revived the concept of combining economic enterprise with spiritual goals, and eventually succeeded in achieving baptisms and producing Indigenous preachers, this was not without substantial and sustained funding from government, Australian congregations and mission organisations that provided Indigenous people with some 
measure of welfare. Such provisions were well beyond the scope of a self-supporting 'Godly mechanic' offering prayer and work.

\section{Endnotes}

1 J. Jupp, Immigration (Melbourne: Oxford University Press, 1998); R. Haines, Nineteenth century government assisted immigrants from the United Kingdom to Australia: Schemes, regulations and arrivals, 1831-1900 (Adelaide: Flinders University, 1995), pp. 25-31.

2 Andrew Bonnell and Rebecca Vonhoff, 'Introduction', in Germans in Queensland: 150 years (Berlin: Peter Lang, 2012), p. 1.

3 Walter Veit (ed.), The struggle for souls and science: Constructing the fifth continent. German missionaries and scientists in Australia (Alice Springs: Strehlow Research Centre, 2004); Susanne Zantop, Colonial fantasies: Conquest, family and nation in precolonial Germany, 1770-1870 (Durham, NC: Duke University Press, 1997); J. P. Weiss, In search of an identity: Essays and ideas on Anglo-Australians, German-Australians and others (Berlin: Peter Lang, 2000); R. Wendt (ed.), Sammeln, Vernetzen, Auswerten. Missionare und ihr Beitrag zum Wandel europäischer Weltsicht (Tübingen: Narr, 2000); G. W. Stocking (ed.), Volksgeist as method and ethic: Essays on Boasian ethnography and the German anthropological tradition (Madison, WI: University of Wisconsin Press, 1996); Anna Kenny, The Aranda's Pepa: An introduction to Carl Strehlow's masterpiece Die Aranda-und Loritja-Stämme in ZentralAustralien (1907-1920) (Canberra: ANU Press, 2014).

4 Alas, the records of the early years of the Gossner mission college, from which the Zion Hill group came, have been lost. Two extended searches and visits in the archives of the Evangelisches Zentralarchiv in Berlin convinced me that these records most likely fell victim to fire in the bombing of Berlin at the end of World War II.

5 Christine Lockwood, 'The two kingdoms: Lutheran missionaries and the British civilizing mission in early South Australia' (unpublished PhD thesis, University of Adelaide, 2014).

6 These data are emerging from an ARC Future Fellowship on German missionaries in Australia (2011-15), and will eventually be published at http://missionaries.griffith.edu.au, where much of the material below already appears. Researchers and co-authors of the already published material regarding these early missions were third-year history students at Griffith University in 2009: Catherine Langbridge, Robert Sloan, Lilia Vassilief, Karen Laughton, Zoe Dyason and Jillian Beard.

7 The only exception was a short-lived attempt at Somerset, Cape York, by two members of the Society for the Propagation of the Gospel, 1867-68.

8 The party consisted of five married artisans - weaver Ambrosius Theophilus Wilhelm Hartenstein (1811-61) and his wife Christina; butcher and cook Johann Gottfried Haussmann (1811-1901) and Wilhelmina (née Lehmann); stonemason and bricklayer Johann Peter Niqué (1811-1903) and Maria (née Bachmann); joiner and cabinetmaker Franz Joseph August Rodé (1811-1903) and Julia (née Peters); and blacksmith Johann Leopold Zillmann (1813-92) and Clara — and four single artisans — shoemaker and bookbinder August Christopher Albrecht (sometimes rendered as Olbrecht) (b. 1816), gardener Ludwig Döge, tailor Friedrich Theodor Franz (1814-91) and shoemaker Johann Gottfried Wagner (1809-93). Reverend Wilhelm Schmidt, accompanied by his wife Hanna Louisa, was placed in charge, assisted by Reverend Christopher Eipper (1813-94) with Harriet (née Gyles). Medical missionary Moritz Schneider (?-1838), also Basel-trained, was accompanied by his wife Maria (née Weiss), who later married Wagner. In 1844, Carl Friedrich Gerler and J. W. Gericke arrived to replace Albrecht and Döge.

9 For a useful comparison with contemporary missions, see also Neil Gunson, 'The Nundah missionaries', Journal of the Royal Historical Society of Queensland 6(3) (1961), 511-39. 
10 Reverend Lancelot Threlkeld had been prevented from establishing a mission at Moreton Bay. Neil Gunson (ed.), Australian reminiscences and papers of L. E. Threlkeld, missionary to the Aborigines, 1824-59 (Canberra: Australian Institute of Aboriginal Studies, 1974), pp. $43-4,84$.

11 Australischer Christenbote, in M. Lohe (ed.), Pastor Haussmann and mission work from 1866 (Adelaide: Lutheran Archives, 1964).

12 J. D. Lang, Reminiscences of my life and times (Melbourne: Heinemann, 1972), p. 143.

13 The Colonist, 10 March 1838, 2, http://nla.gov.au/nla.news-article31720572.

14 Eipper's journal states that they 'were under the guidance of three natives, Wunkermany and the two brothers, Wogann'. It also refers during the same journey to Wagner's brother Anbaybury, 'my brother Dunkley' and Jemmy Millboang.

15 'Observations made on a journey to the natives at Toorbal, 2 August 1841 by the Reverend Christopher Eipper, of the Moreton Bay German Mission: Journal of the Reverend Christopher Eipper, Missionary to the Aborigines at Moreton Bay 1841', http://missionaries.griffith.edu.au/excerpts-christopher-eipper.

16 John Harris, One blood: 200 years of Aboriginal encounter with Christianity: A story of hope (Hamburg: Albatross Books, 1990), p. 111; Niel Gunson, 'Schmidt, Karl Wilhelm Edward (-1864)', in Australian Dictionary of Biography (2006), http://adb.anu.edu.au/biography/schmidt-karl-wilhelm-edward-2635. Ray Evans specifies that this incident occurred on 21 March 1840, and Dennis Cryle, in the same volume, refers to John Steele to say that several were wounded. Ray Evans, 'The Mogwi Take Mi-an-jin', in Rod Fisher (ed.), The Brisbane Aboriginal presence 1824-1860 (Brisbane: Brisbane History Group, 1992), pp. 7-30; Dennis Cryle, 'Snakes in the grass', in Fisher, The Brisbane Aboriginal presence 1824-1860, p. 72; John Steele (comp.), Brisbane town in convict days, 1826-42 (Brisbane: University of Queensland Press, 1975), p. 268.

17 'Polding to Murphy, Moreton Bay, 2 July 1843', in Reverend Osmund Thorpe CP, First Catholic mission to the Australian Aborigines (Sydney: Pellegrini, 1950), p. 191.

18 'Polding to Franzoni, Sydney, 10 April 1845', in Thorpe, First Catholic mission, p. 194.

19 Three of them intended to join the planned Benedictine mission in Western Australian (New Norcia), but were placed in South Australia instead. 'Vaccari in Sydney to Mgr Pione Colmo, 15 March 1843', in Thorpe, First Catholic mission, p. 209.

20 'Evidence by Tom Petrie', in Native Police Force Report, 1861, Queensland Legislative Assembly, http://www.aiatsis.gov.au/_files/archive/removeprotect/92123.pdf.

21 'Polding to Cardinal Franzoni'.

22 'Evidence by Rodé and Zillmann', in Native Police Force Report, 1861, Queensland Legislative Assembly, http://www.aiatsis.gov.au/_files/archive/removeprotect/92123.pdf.

23 It is not possible to specify which language Bracefield spoke. Tindale shows several languages in that region, including Turubul spoken by the Jagara, and the Batjala and Kabi-Kabi further north. See http://archives.samuseum.sa.gov.au/tindaletribes/jagara.htm. Bracefield (or Bracewell) returned from Wide Bay in 1842 and died in 1844. Niel Gunson, 'A missionary expedition from Zion Hill (Nundah) to Toorbul, Moreton Bay District, in 184243: The journal of the Reverend K. W. E. Schmidt', Aboriginal History 2 (1978), 11421.

24 J. D. Lang, Cooksland - or the Moreton Bay District of New South Wales (London: Longman, Brown, Green and Longmans, 1847), pp. 471-2.

25 The curtain of silence over known incidents of flour poisoning in Queensland is discussed by several contributions in Fisher, The Brisbane Aboriginal presence 18241860. 
Regina Ganter

26 Fisher, The Brisbane Aboriginal presence 1824-1860.

27 'Polding to Cardinal Franzoni'.

28 Wagner, Rodé, Zillmann, Franz, Hartenstein and Gerler became residents of German Station.

29 Moreton Bay Courier, classified advertising, 22 April 1854, 1, http://nla.gov.au/nla.newsarticle3713922.

30 Jeanette Nolan, 'Pastor J. G. Haussmann: A Queensland pioneer, 1838-1901' (unpublished Honours thesis, University of Queensland, 1964).

31 These pressures were evident even earlier: Geelong Advertiser, 25 July 1842, 3, http://nla. gov.au/nla.news-article92673790.

32 B. Hedges, 'German settlement in the Beenleigh area in the nineteenth century' (unpublished MA thesis, University of New England, 1994), p. 38.

33 Franz, Gericke, Rodé, Gerler, and Zillmann attended the meeting.

34 Moreton Bay Courier, 17 February 1855, 2, http://nla.gov.au/nla.news-article3709402.

35 Jonathan Richards, The secret war: A true history of Queensland's native police (Brisbane: University of Queensland Press, 2008).

36 'Evidence by Zillmann, Q.73', in Native Police Force Report, 1861, Queensland Legislative Assembly, http://www.aiatsis.gov.au/_files/archive/removeprotect/92123.pdf.

37 'Schmidt, Karl Wilhelm Edward (-1864)', Australian Dictionary of Biography (2006), http://adb.anu.edu.au/biography/schmidt-karl-wilhelm-edward-2635.

38 An excellent discussion of Nathaniel Pepper is in Robert Kenny, The lamb enters the dreaming -Nathanael Pepper and the ruptured world (Melbourne: Scribe, 2007).

39 Nolan, 'Pastor J. G. Haussmann', p. 95.

40 'Evidence by Zillmann', in Native Police Force Report, 1861, Queensland Legislative Assembly, http://www.aiatsis.gov.au/_files/archive/removeprotect/92123.pdf.

41 Wagner, Niqué, Hausmann, Gerler and Gericke achieved ordination.

42 Queensland Daily Guardian, 1 November 1864, letter to the editor from 'Anti-Humbug' (not digitised), cited in Nolan, 'Pastor J. G. Haussmann'.

43 Haussman ordained A. D. Hartwig (1875), C. Berndt (1876) and the Gossner-trained candidates F. Copas (1865), F. W. Burghardt (1866) and C. Gaustadt (1869). For Gaustadt, ordained by Haussman according to Nolan, the LAA Directory of Lutheran Pastors is uncertain of time and place of ordination. Nolan was uncertain about the ordination of Christian Berndt, who is listed in the LAA directory as a Haussman candidate: 'As a result of controversy with Pastor Haussmann his name was struck off the roll of Lutheran ministers. He was then registered as a "Congregational Lutheran" minister in Queensland and served the only "Congregational Lutheran Church" in Australia (and most likely the world) at Hillside (Hatton Vale). He was married, but no details are available.' LAA Directory of Lutheran Pastors.

44 Philip Holzknecht, 'A priesthood of priests? The German Lutherans in Queensland', in Manfred Jurgensen and Alan Corkhill (eds), The German presence in Queensland (Brisbane: University of Queensland Press, 1988), pp. 155-73.

45 Nolan, 'Pastor J. G. Haussmann', pp. 106-7.

46 Holzknecht, 'A priesthood of priests?', pp. 155-73.

47 Nolan, 'Pastor J. G. Haussmann', p. 86, citing Reverend Scheer's speech at St Peter's in Beenleigh on the fiftieth anniversary of the German settlement at Waterford.

48 Nolan, 'Pastor J. G. Haussmann', p. 86. 
49 The only other attempt in Queensland during the 1860s was at Somerset (1867-68). Edward Fuller began itinerant missions at Fraser Island and elsewhere in 1871.

50 According to Nolan, the Gossner trained candidates arriving in January 1866 ready for ordination were Theodor Langebecker, Gottlieb Wilhelm Guhr, Friedrich Wilhelm Burghardt and John Hausmann. Holzknecht ('A priesthood of priests?') also lists Gottfried Hampe, Friedrich Copas, August Fahr, David Pfunder and Hermann Mix, but does not mention John Hausmann.

51 Hausmann, Australischer Christenbote, February 1867, in Lohe, 'Pastor Haussmann'.

52 Hausmann, Australischer Christenbote, November 1866, in Lohe, 'Pastor Haussmann'.

53 Lohe, 'Pastor Haussmann'.

54 The LAA Directory of Lutheran Pastors records that John Hausmann (1843-1900) returned to Queensland in 1866 after receiving university theological training in Germany and theological practice at the Gossner Mission Society in Berlin. It does not record his ordination, and indicates that he was a member of the Immanuel synod in 1866, serving in Rockhampton and Mackay, and that he spent a short time as a Presbyterian bush missionary. (The LAA Directory only records Lutheran activity.) In 1874, he was one of four commissioners investigating the condition of Aborigines in Mackay. The report makes no reference to an ordained status, but also does not indicate the prominent positions of his three co-authors. Holzknecht ('A priesthood of priests?') describes him as a 'registered Presbyterian'.

55 Friedrich Wilhelm Burghardt (1844-1917) from Silesia was ordained in 1866, became a member of the Immanuel synod (1866-90), assisted Haussman at Beenleigh 1866-67, ministered at German Station (1867-73), taught at St Paul's in Toowoomba (1874-82), at Highfields Christ (1882-94), at German Station and Zillmere (1895-99), and Highfields Holy Trinity (1900-17). LAA Directory of Lutheran Pastors.

56 Gottlieb Wilhelm Guhr (1842-1919) from Tannenberg, Silesia, became Haussman's assistant at Bethesda mission (1866-70). He taught at St. Paul's in Toowoomba (1871-86), was ordained in 1887 and then became an itinerant pastor in various Queensland parishes (1887-90) and at Gombungee (1888-1908) and Glencoe (1890-1905). LAA Directory of Lutheran Pastors.

57 Hausmann, Australischer Christenbote, February 1867, in Lohe, 'Pastor Haussmann'.

58 Hausmann, Australischer Christenbote, July 1869, in Lohe, 'Pastor Haussmann'.

59 Hausmann, Australischer Christenbote, February 1867, in Lohe, 'Pastor Haussmann'. On the question of Aboriginal understandings of Christian rituals as 'human sacrifice', Debbie Rose and Stefano Girola also offer interesting observations. Deborah Bird Rose, 'Signs of life on a barbarous frontier: Intercultural encounters in North Australia', Humanities Research 2 (1998), 17-31; and S. Girola and E. Franchi, 'Constructing otherness and past through creative mistakes: Ancient initiation war and contemporary human sacrifices', in G. Proietti and E. Franchi (eds), Forme della memoria e dinamiche identitarie nell'antichità grecoromana (Trento: University of Trento, Department of Philosophy, History and Culture, 2012), pp. 229-66.

60 On the Aboriginal understanding that they were getting paid for praying and listening see, for example, C. Anderson, 'A case study in failure: Kuku-Yalanji and the Lutherans at Bloomfield River, 1887-1902', in T. Swain and D. B. Rose (eds), Aborigines and Christianity: Anthropological and historical studies (Adelaide: Australian Association for the Study of Religion, 1988), pp. 321-37; Chris Anderson, 'Was God ever a boss at Wujal-Wujal? Lutherans and Kuku-Yalanji: A socio-historical analysis', Australian Journal of Anthropology 21(1) (2010), 33-50; Kay Saunders (Kay Evans), 'Missionary effort towards the Cape York Aborigines, 1886-1910: A study of culture contact' (BA (Hons) thesis, University of 
Queensland, 1969); John and Leslie Haviland, “'How much food will there be in heaven?' Lutherans and Aborigines around Cooktown to 1900', Aboriginal History 4(1-2) (1980), 119-49.

61 It is tempting to read 'Papo' as a typing error for the German 'Papa'. However, the Aranda at Hermannsburg called Carl Strehlow 'Pepa', which means both 'paper' and 'law' and refers to his evangelical position of power. Kenny, The Aranda's Pepa.

62 Hausmann reported only in the Victorian Lutheran newsletter Australischer Christenbote.

63 Nolan, 'Pastor J. G. Haussmann', p. 100, referring to Australischer Christenbote, October 1868.

64 'After a two-day journey we arrived there. My two native friends soon found the camp of natives and Kingcame informed the natives who I was and what I wanted. They asked me to remain with them, as they wanted to live with me ... My two native guides and friends decided to remain here so that they could be a mediator between the various tribes.' Hausmann, Australischer Christenbote, July 1869, in Lohe, 'Pastor Haussmann'.

65 On 21 August 1871, an 'Official Notification' appeared in the Brisbane Courier).

66 Australischer Christenbote, 3 October 1871, in Lohe, 'Pastor Haussmann'.

67 In 1877, Haussman assembled a credible and much larger Nerang Mission committee and a small band of volunteers: C. Thiedeke from Toowoomba (with wife and three children), bachelor Kabisch and a Reverend Tedekin, recently arrived from Germany and locally ordained (also referred to as Mr. Dedekind). The latter left shortly afterwards, and by the end of 1878, only Kabisch was left. Australischer Christenbote, February 1878, in Lohe, 'Pastor Haussmann'.

68 Report by W. L. G. Drew, A. C. Gregory, Charles Coxen and John G. Hausmann, 'Aborigines of Queensland: Report of the commissioners for the purpose of taking into consideration certain questions opened up by a petition from a number of residents in the district of Mackay, relative to the employment and protection of the Aboriginal inhabitants of the district', Queensland Legislative Assembly, 1874, http://www.aiatsis.gov.au/files/archive/removeprotect/92128.pdf.

69 In 1876, there were three camps: Goonenberry, about 6 miles from the mouth of Sandy Creek (commenced in 1875); Carrobaya, about 2 miles from the mouth of Sandy Creek (commenced in 1876); and Tullaboi, at the mouth of the Creek; see 'Report of Board of Inquiry appointed by the Secretary for Lands to inquire into and report upon the state of the Aboriginal reserve at Mackay, 1876', http://www.aiatsis.gov.au/_files/archive/removeprotect. The Mackay reserve was declared in 1877: Ros Kidd, The way we civilize (Brisbane: University of Queensland Press, 1997. It was cancelled in 1880: Kathy Frankland, A brief history of government administration of Aboriginal and Torres Strait Islander Peoples in Queensland, http://www.slq.qld.gov.au/data/assets/pdf_file/0008/93734/Admin_History_Aboriginal_ and_Torres_Strait_Islanders.pdf).

70 See the government correspondence with McNab in the 1876 Queensland Legislative Assembly, http://www.aiatsis.gov.au/_files/archive/removeprotect/92144.pdf.

71 Kidd, The way we civilize, p. 27.

72 This was the experience of the Moravians in Victoria in the 1870s, Daniel and Janet Mathews at Maloga in the 1880s and the Trappists in the Kimberley (1890-1900). As Victorian Protector of Aborigines, the Moravian Hagenauer had to explain this policy to Johann Flierl, seeking to place the Lutheran missions in north Queensland on a secure footing, capable of surviving government policy shifts. 'Board for Protection of Aborigines, Melbourne, to Johann Flierl, Tanunda, November 24, 1898 in 1.6.35 Reuther, Georg, 18611912', Pers. Korresp. Vorl. Nr. 4.93/5, Neuendettelsau. 
73 Reverend Matthias Goethe, Australischer Christenbote, August 1877, in Lohe, 'Pastor Haussmann'.

74 'Letter by six German-descent citizens of Walloon, 6 September 1875', Herrnhut Archives, R.15.V.I.a.7.8 Verschiedene Pläne und Versuche-Queensland. The letter is signed by Haussmann, F. W. Burghardt, Christopher Gaustadt, Gottfried David Hauser, August Daniel Hartwig and E. G. H. Lehmann. It refers to the failed attempts of an 'eager young preacher' (Edward Fuller, see below).

75 Nolan, 'Pastor J. G. Haussmann', 97, citing the Jubiläumsschrift for Haussman's ninetieth birthday. Holzknecht ('A priesthood of priests?', p. 164) relates that Haussmann ordained a layman, Christian Berndt, in 1879 and later had a falling out with him that led to a congregational three-way split.

76 Australischer Christenbote, 1881, in Lohe, 'Pastor Haussmann'.

77 Australischer Christenbote, in Lohe, 'Pastor Haussmann'.

78 The Queensland missions that lasted less than a year were the Society for the Propagation of the Gospel Ministers at Somerset (1867-68) and Edward Fuller at Fraser Island (1871), Noosa River (New South Wales, 1872), Hinchinbrook Island (1873) and Bellenden Plains in North Queensland (1874).

79 The long-term mission projects were the Pacific Island missionaries stationed in the Torres Strait by the London Missionary Society in 1871 to encourage copra production, the Church Missionary Society at Bowen (1878-1901) and Catholic Reverend Duncan McNab at Durundur (1877-1885). According to Kidd (The way we civilize, p. 27), the Durundur reserve was formally closed in 1905 and its remaining residents transferred to Barambah.

80 Lockwood, 'The two kingdoms', pp. 163-8 suggests that any mission operating for under ten years is not likely to produce baptisms.

81 'Biographical notes', Lutheran Almanac (1965), 27-37.

82 Jock Schmiechen, 'The Hermannsburg Mission Society in Australia 1866-1895: Changing missionary attitudes and their effects on the Aboriginal inhabitants' (unpublished BA (Hons) thesis, University of Adelaide, 1971), pp. 2-4.

83 Lockwood, 'The two kingdoms'.

84 Lockwood, 'The two kingdoms'.

85 Australischer Christenbote, in Lohe, 'Pastor Haussmann'. 